Row over nuclear safeguards continues

IAEA official

\section{denies evidence}

\section{to Congress}

The evidence given by Dr Roger Richter in the past few weeks to the foreign relations committees of the United States Congress was distorted, partly for effect and partly out of ignorance, according to Dr Hans Gruemm, the Austrian physicist who is head of the safeguards division of the International Atomic Energy Agency (IAEA). Dr Gruemm was speaking at a conference of the Institute of Nuclear Materials Handling in San Francisco on Monday this week.

In his address, Dr Gruemm acknowledged that the attack on the Iraqi reactor at Tamuz on 7 June, and the public comment that had followed - as well as Dr Richter's removal of confidential papers from the agency - had undermined the credibility of the safeguards system. He said, however, that the agency's internal memorandum dated 10 March, made public during the Senate hearings, was only one of several documents circulating within the agency and concerned with the improvement of safeguards on large research reactors.

The memorandum of 10 March, addressed to Dr Gruemm by Dr T. Shea of the agency's safeguards division, is a minute of a staff meeting on 12 February called to consider the feasibility of closing two loopholes in the agency's safeguards procedures - the possibility that a state covered by inspection might not have declared all the nuclear material used in its operations, and the possibility that reactors under safeguards might be used for making plutonium (or uranium-233) by the clandestine irradiation of natural uranium (or of thorium).

The meeting concluded that it would not be feasible to detect undeclared stocks of nuclear materials except by means of country-wide surveillance not covered by the safeguards provisions. On the use of reactors for the production of fissile material by neutron bombardment, the meeting apparently acknowledged that routine inspection would not always detect the use of uranium or thorium in this way because of the frequency with which samples for irradiation would normally be loaded and withdrawn (as in the production of short-lived isotopes), listed five technical devices that might serve continuously to monitor such illicit uses, agreed that none had been "identified" as "effective and efficient" and suggested further study. Dr Richter, in his account of these proceedings, did not say that the

agency was concerned.

Dr Gruemm said in San Francisco this week that the meeting in Vienna in February (at which Dr Richter had not been present) was only one of several technical meetings called to discuss improvements of safeguards procedures made possible by the recruitment of extra inspectors. He complained that Richter had not mentioned that studies of the feasibility of detecting the use of research reactors for manufacturing fissile material had been begun in 1980 .

Dr Gruemm also said that detailed studies of the Tamuz reactor as a means of producing clandestine fissile material were begun at the end of 1979, when the agency was first informed of the transfer of natural and depleted uranium to Iraq. The agency's calculations showed that it might be possible to produce between one and two "significant quantitics" (bomb units) of fissile material each year, but that this would be possible only by replenishing the

\title{
Chevènement still battling for control
}

The nouvelle politique of science in France is off to a shaky start. Jean-Pierre Chevènement, Minister of State for Science and Technology, is still struggling with the Ministry of Industry for the control of certain key institutions; while on the other wing the more radical unions are calling for the resignation of certain research directors of the old regime.

The minister's contribution, announced last week, to the new 1981 budget - an adjustment to that of the previous government's - also falls a long way short of what he must aim for to bring French research and development spending up to the promised 2.5 per cent of gross national product by 1985 . He will ask the National Assembly for an additional FF 154.9 million (around $£ 15$ million) compared with a total 1980 expenditure of FF 14,500 million, excluding defence research. That amounts to a 1 per cent increase; $M$. Chevènement will need ten times as much next year.

Of this year's extras, the minister will ask for FF 68.5 million to pay new salaries at the Centre National de la Recherche Scientifique (CNRS) - the main basic research agency - and at the Institut National de la Recherche Agronomique. Chevènement foresees the creation of 525 new posts, most of them for technicians and administrators. Then FF 25 million would prop up the contribution to the European centre for nuclear research (CERN) against the recent fall in the French franc. And FF 61.4 million would increase running budgets - but not of the basic research agencies. The Agence Nationale pour la Valorisation de la Recherche, which helps to convert discoveries in French laboratories into reactor core "several times a year" with enriched uranium, presumably from France. To make optimum clandestine use of the reactor, it would also have been necessary to add cooling circuits to the reactor, which would have been visible on inspection.

Dr Gruemm's statement in San Francisco is, however, unlikely soon to still the argument about the efficacy of the agency's safeguards, even though the agency appears to have resolved its previously chronic manpower problems its professional safeguards staff increased fourfold (to 206) between 1970 and 1980.

Meanwhile, interest in the capacity of Israel to manufacture nuclear weapons has been revived by the report of a panel appointed by the United Nations, including Dr George Quester of Cornell University as its United States representative, that Israel is probably now in a position quickly to produce a substantial number of nuclear weapons. innovations in French industry - and is rather a pet of M. Chevènement's - would get FF 60 million, and the remaining FF 1.4 million would go to the Centre National pour l'Exploitation des Océans to create fish farms.

Meanwhile Chevènement is struggling to establish his authority over the nonmilitary research activities of the atomic energy and space authorities (CEA and CNES), and of the Agence Nationale pour la Valorisation de la Recherche itself, all of which at present belong to the Ministry for Industry. Chevènement's determination to control these agencies, in one way or another, and so to have - through the management of innovation - a major say in the socialist transformation of French industry, is not going down well among industry ministry bureaucrats, and they are now briefing their second minister in a few months, M. Pierre Dreyfus, to resist the scientific upstart.

However, Chevènement will almost certainly gain control of the Centre National de la Recherche Scientifique, where the unions - to whose interests Chevènement is sensitive - are becoming active. Most dramatically, the communistaffiliated Syndicat National des Chercheurs Scientifique last week called for the resignation of both the president and director of CNRS, Professor Charles Thibault and M. Jacques Ducuing. The director-general of the medical research agency, INSERM, M. Philippe Laudat, should also resign, said the union. They stand in the way of progress, according to the union secretary-general M. Michel Gruselle. Chevènement is cryptic; when asked recently if heads would roll, he said "we shall see".
Robert Walgate 